\title{
Nature Study as a Learning Method of Character Education for Homeschooling Learners
}

\author{
$1^{\text {st }}$ Rebecca Evelyn Laiya \\ English Education Study Program \\ STKIP South Nias \\ Indonesia \\ harumiharazaki@gmail.com
}

\begin{abstract}
Homeschooling is one of the learning ways recognized by the Indonesian state, namely informal education. Based on Act of the Republic of Indonesia on National Education System No. 20, year 2003 it is explained that there are three kinds of learning ways in Indonesia, namely formal education, non-formal education and informal education. Moreover, based on Act of the Republic of Indonesia on National Education System no 20 article 1 chapter 27 no 20 of 2003 states "Informal education means family education and education in surroundings", so homeschooling is not an institution. Learning methods of homeschooling learners are more flexible than formal education, because the principle of learning homeschooling is learning anywhere, anytime, and with anyone. Flexibility does not mean it does not have a good benefit. One method of learning is a learning model introduced by a British educational figure named Charlotte Mason. Mason introduced a learning model called nature study. Nature study means briefly learning in nature, learning from nature. This study is a qualitative descriptive study with the aim of describing the results of character building through nature walks conducted for homeschooling learners. By using observation and interviews for data collection. Then analyzed using steps introduced by Creswell and Gay Mills. Then the results obtained that nature study can mold the characters for homeschooling learners they are: devotion, The conclusion obtained is that character education should be done by applying it in daily life, one of them is through nature study.
\end{abstract}

Keywords-Nature Study, Learning Method, Character, Homeschooling

\section{INTRODUCTION}

Homeschooling is one of three ways of learning in Indonesia. There are three kinds of learning ways in Indonesia namely formal education, non-formal education and informal education and homeschooling is an informal education [1]. However, some people until know still do not really know what is homeschooling though it is already explained "Informal education means family education and education in surroundings" [2]. People in Indonesia think that homeschooling is an institution which provide education service, however it is an education provided by the parents and environment The teaching and learning activities in homeschooling is more flexible because the individual who arrange the activities are parents and the homeschooler learner.(children).

Basically homeschooling education is not a very new educational path. Based on the Latin word school comes from the word schola and scola while based on the Greek word skhole which both mean free time. In ancient times schools were not institutions but free time used by parents to bring their children to visit a place or someone so their children could learn. So the school is something fun, the school actually draws children closer to their parents rather than forming anger and trauma [3].

\section{A. An Introduction of Charlotte Mason}

Charlotte Mason is a British educator who had an opinion. Her trusted that education is more than to train the students in order to the job or pass the exam. According Mason education is an atmosphere, a discipline is a life, education also must train the students to know who are they and how the students fit into the world of human being and into the universe God created [4].

Charlotte Mason agreed that students have an ability to understand ideas and knowledge. Students are not an empty slate. According Mason to get the noble ideas and knowledge students through the book and through art, music and poetry. The knowledge about God found in the Bible or other religious text this is the most important knowledge. History taught chronological using a well written book source documents and biographies. Literation taught through the history from the book. Language art skills by ask the student to do naration, the students are asked to tell back the history firstly orally and later in written form from the well written book or dictation of passages from their book. Memorization is used but not to memorise the assimilate facts, but to make the students to meditate what they memorise, what they memorise are scripture or poetry. The students are also learn the science through nature study, by should be applied oiyrfocusing the observation the creation of God as a means the knowldege of God. Its Charlotte Mason advised that learning should not be very long, it should be in a short time (10 until 20 minutes for younger learners but longer for the older one) [5].

B. Nature Study 
Nature is a great place for children to learn. Charlotte Mason explain in her book that everyone need an oxigen in order to keep the body strong and healthy. Ideally children must live near the country because they need fresh air and sun. To make the children fat is very easy, but fat it does not mean healthy. Children with "the bright eyes, open nature, bounce in the step, clear voice, coordinated, graceful movements" are abosolutely healthy, because they have a well mind and soul. Those are the characteristics of the children who has a quick, alert mind and morality and having a great ability to be happy and self controlled.[6] Thus the children need to learn nature through the real environment through the in outdoor, not only through the theory.

Nature study is a way for the children to learn the environment. Since according to Charlotte Mason education is an atmosphere means the parents must be a role model for the children, thus in nature study parents must learn the environment also together with their children. Parents can stimulate the student by leading them to see many things which are interesting in the environment. Children may report to the parents by saying "There's a beehive.' 'Lots of bees were going in it.' 'There's a long garden.' 'It had sunflowers. Step by step parents will get a complete details. In other words actually the children doing an observation by doing sight seeing and giving the result of observation to the parents.[7]

The following step after doing observation the children finally is given the opportunity to do a picture painting. While they are painting, they learn the nature more detail. Beside the children also learn the calender, they know the right time to grow a certain flower or the right time to see a beautiful view in the nature. And finally the children can make a journal about what the children have seen and learn from the nature [8]. In conclusion there are some steps to apply the nature study including (1) doing observation (2) report what the children have seen to the parents (3) study the calender and (4) making a journal.

\section{Character Education}

Character education is essential. Before considering about character education it would better to ground the definition of character. According Berkowitz character as an 'individual's set of psychological characteristics that affect that person's ability and inclination to function morally" [9]. It is what leads a person to do the right thing or not to do the right thing. Further, he proposed so called Moral Anatomy comprising psychological components which constitute a moral person. There are seven parts to the moral anatomy: moral behavior, moral values, moral personality, moral emotion, moral reasoning, moral identity, and foundational characteristics. Besides Berkowitz explains that the sources of character consists of on some places they are family, school and community. Parents are to role model for their children, how the parents showing the values, respecting the children and also opening the discussion will give the knowledge for the children to learn the character. School effects the children to have child' a self-concept, social skills. Values, moral reasoning. Then finally society through media exposure, neigbohood characteristics and cultural values.

According Charlotte Mason curriculum character education is more important than academic purpose. If the children have a good character at the end of their education they will try to do their best in doing their responsibility thus character is very important. There are 20 principles of Charlotte Mason the first principle is children is a born person, they have a potency to be good or to be bad. Because of that fact Charlotte Mason advised the parents to train the children base on three pillars of education they are education is an atmosphere, education is discipline, education is a life. Education is atmosphere means education is making a good environment for the children and parents must show a good example for their children. Education is discipline, means education should train the children to have a good habit and finally have a good character. Education is a life, education must give ideas for the children, by giving them a good story that are able to spread ideas for the children [10].

Indonesia decided 18 values originated from Pancasila, religions, culture and the objectives of national education which are prioritized as the objectives of CE in 20102014, they are: 1) religiousness, 2) honesty, 3) toleration, 4) discipline, 5) hard work, 6) creativity, 7) independence, 8) democratic, 9) curiousness, 10) nationalism, 11) patriotism, 12) achivement oriented, 13) communicative and friendly, 14) peacefulness, 15) keen of reading, 16) enviromentally savvy, 17) social care, and 18) responsibility.[6]

In the era of $21^{\text {st }}$ century where humanity is losing there are some problems happened in this world they are environmental issues, corruption, terrorism, income inequality. Because of those problems children needs to have character education (https://themp.org). The one who is good in mathematic is not enough if he does not have a good character therefore character should be applied. There are some qualities that the children need to be achieved in the era of $21^{\text {st }}$ century they are (1) mindfulness (2) curiosity (3) resilence (4) courage (5) ethics (6) leadership [11]

\section{RESEARCH METHODS}

This research is a descriptive qualitiative with the aim of describing the results of character building through nature walks conducted for homeschooling learners. The participant of this research is her daughter she is 8.5 years old and one of homeschooler family and the children 13 years old and 6 years old. The researcher did the observation by observing all the children and parents activities in applying the nature study and also did the unstructured interview. The researcher analyzing the data using some steps introduced by Creswell and Gay Mills they are (1) organize and prepare data for analyzing (2) study in detail all the data (3) the data are coded (4) use the process of coding to describe the setting and the theme of the data (5) make a qualitative narrative (6) making an interpretation [12] 


\section{A. Research finding}

\section{RESULT AND DISCUSSION}

The application of homeschooling learning is different from formal education, because the process of learning is not in the class most of the time but at home. The person who act as the headmaster is the parents, the teacher can be the parents but also someone who parents already trusted to teach their children. Eventhough the process at home most of the time but the process of learning could be anywhere. The place to apply nature study is on the real environment. The place where the children can have a great sightseeing and enjoy the fresh air. Thus the children can learn the nature through the nature itself not from the theory that maybe they never have seen. Through the nature study the children not only learn the nature but also learn the character education.

This result base on the observation and interview by the researcher from her own daughter. Her daughter is 8.5 years old and some homeschooling leaners and homeschooling parents.

The character qualities have been achieved by the children are :

\section{Devotion (religiousness)}

Nature study directs children to admire God's creations so that he realizes that the environment must be protected. In addition, children learn to reflect on how beautiful His creation is and they are only a grain of dust in the middle of God's created universe and they must appreciate that this nature does not do anything arbitrarily towards this nature.

\section{Integrity}

In the nature study process it also teaches children to have good integrity. When children are ordered to keep a journal of what they observe in nature honestly there is no need to increase or decrease the information they provide.

\section{Curiosity}

Children also have a high curiosity, because the more they pay attention to what is happening in nature the more curious the children want to find out. For example, about the process of butterfly metamorphosis. In nature children see the caterpillars directly eat so many leaves they increasingly want to know what happens after the caterpillars eat so many leaves, then after that it becomes a cocoon, when the cocoon turns into a butterfly and so on.

\section{Persistence}

In addition, children also learn to be persistent in facing challenges, because in conducting nature study children do nature walks, means walking in the natural environment, of course when walking they become tired, also because they are exposed to be sweat. But even though they are tired and sweaty they keep on persevering because they enjoy the trip, because they will see many interesting things in the universe

\section{Adaptability}

In the implementation of nature study, children also learn to adapt because of course when the children are in the field, there are things that cannot be controlled and regulated, for example the possibility of being bitten by mosquitoes and other insects or the possibility of rain or scorching heat as well as the possibility of going up and down the hill and others. By dealing with things that are unexpected in nature, teach children to be able to adapt in any circumstances whether pleasant or unpleasant.

\section{Leadership}

Nature study also teaches children leadership. When they do nature study, children must obey certain rules, including obeying to report to parents, honestly reporting what happened is not added or subtracted, consistent in making observations. In obeying those rules train the child to become a leader.

\section{Social and Culture Awareness}

In nature study children indirectly have social and cultural awareness. This is because when nature study applied children also must be able to interact with nature and other people. In addition, children are also able to recognize the culture of Indonesia or the culture of their respective regions when they visit an environment. Of course they realize that there are certain animals or plants that are typically owned by tropical countries and specifically only owned by the Indonesian state even in certain regions only in Indonesia. Thus nature study is very useful for developing character.

\section{B. Discussion}

All the quality of characters found in nature study for children is a quality that really needs to be owned by children to live in this 21 st century. So nature study has two advantages for children. Children can learn about nature and also improving character quality.

\section{CLOSING}

\section{A. Conclusion}

Character education should be applied in daily life, not just theory. Nature study is an effective way for children especially for homeschooling learners where their learning activities can be arranged in such a way. It is also an alternative for children who are currently studying online at home. Parents can apply this even if only in the garden of their own home

\section{B. Recommendation}

Nature study is actually not limited to homeschoolers but for all children. Parents can use this activity, through this activity children not only can learn nature but also increases the quality of character and also the bonding between parents and children.

\section{REFERENCES}

[1] Act of the Republic of Indonesia on National Education System No. 20, year 2003

[2] Act of the Republic of Indonesia on National Education System no 20 article 1 chapter 27 no 20 of 2003.

[3] Topatimasang, Roem. 2007. Sekolah Itu Candu, Jogjakarta, Insist Press,

[4] White, https://www.amblesideonline.org/WhatIsCM.shtml

[5] Mason, Charlotte, Home Education Vol 1 of Charlotte Mason Series,

https://www.amblesideonline.org/CMM/M1 complete.html\#042.

[6] Mason, Charlotte, Toward a Philosophy of Education Vol 6 of Charlotte Mason Series, https://www.amblesideonline.org/CMM/M6complete.html\#xxv

[7] Mason, Charlotte, Home Education Vol 1 of Charlotte Mason Series,

https://www.amblesideonline.org/CMM/M1 complete.html\#042 
[8] Mason, Charlotte, Home Education Vol 1 of Charlotte Mason Series,

https://www.amblesideonline.org/CMM/M1 complete.html\#042

[9] Berkowitz, M.W. 2002. The Science of Character Education in Damon, W. (ed.). 2002. Bringing in a New Era in Character Education. Standford: Hoover Institution Press.

[10] Mason, Charlotte, Toward a Philosophy of Education Vol 6 of Charlotte Mason Series, https://www.amblesideonline.org/CMM/M6complete.html\#xxv
[11] Puskurbuk. 2011. Pedoman Pelaksanaan Pendidikan Karakter page. 3

[12] Creswell, J. W. 2014. Research Design: Qualitative, Quantitative and Mixed Methods Approaches (4th ed.). Thousand
CA:

Sage) 